Representative Fellow on Council: Dr P. T. d'Orban Representative Member on Council: $\mathrm{Dr}$ J. R. Hamilton

Executive Committee: Drs A. Campbell, B. D. Cooper, Professors T. C. N. Gibbens, J. C. Gunn, Drs H. Hunter, J. A. C. MacKeith, A. McQuaid, H. Milne, I. Pierce James, D. G. A. Westbury, P. G. Woolf

Co-opted: Drs M. Faulk, J. Higgins, R. C. Ingrey-Senn, V. Molony, D. O. Topp

Observer: Dr L. J. F. Warnants

Collegiate Trainees Representative: Dr G. Glancy

\section{Mental Deficiency Section}

Chairman: Dr J. Jancar

Secretary: Dr W. R. McKibben

Representative Fellow on Council: Dr Valerie Cowie

Representative Member on Council: Dr W. R. McKibben

Executive Committee: Drs J. T. Bavin, J. A. Corbett, M. Craft, A. S. R. Goonetilleke, J. A. Hatrick, M. Leyshon, D. M. Lynch, M. Quinn, Gwyn E. Roberts, R. M. Veall, P. Sylvester

Co-opted: Drs F. Broderick, W. I. Fraser, D. A. Primrose, E. W. Shepherd, H. Smyth

Observer: Dr R. Wilkins

Collegiate Trainees Representative: Dr G. Holt

Section for the Psychiatry of Old Age
Chairman: Dr R. A. Robinson
Secretary: Dr P. M. Jefferys
Representative Fellow on Council: Dr R. A. Robinson
Representative Member on Council: Dr P. M. Jefferys
Executive Committee: Professor T. A Arie, Drs K.
Bergmann, G. Blessed, C. Godber, P. Goddard, D. J.
Jolley, G. E. Langley, R. Levy, C. McDonald, G.
Mitchell, R. M. Philpott, B. Pitt, F. Post, P. V. Spencer,
E. R. Taws, C. A. Trotter (Collegiate Trainees
Representative)
Co-opted: Dr J. Fisk
Observer: Dr R. Wilkins

\section{News Items}

\section{Money for Eczema Research}

The Research Fund of the National Eczema Society now stands at around $£ 30,000$ and is open for applications for grants in the region of $£ 1,000$ to $£ 3,000$. The Society is interested in research on all types of eczema and into all aspects of the disease. Applications for funds to assist research in the management of the condition will be given special consideration. Further particulars and instructions on how to apply for a grant may be obtained from the General Secretary, National Eczema Society, 5-7 Tavistock Place, London WC1H 9SR. (Submission date for 1980 is 1 September).

\section{Section of Social and Community Psychiatry}

Chairman: Dr J. P. Leff

Secretary: Dr A. C. Brown

Representative Fellow on Council: Dr J. P. Leff

Representative Member on Council: Dr B. Morris

Executive Committee: Drs J. R. Ashton, D. H. Bennett, A. Brook, J. D. W. Fisher, H. Freeman, Professor S. Hirsch, Drs P. M. Jefferys, J. Lomax-Simpson, B. Morris, C. Parkes, Professor E. Paykel, Drs U. P. Seidel, J. Stuart Whiteley, R. Williams

Observer: Dr A. Sippert

Collegiate Trainees Representative: Dr I. Pullen

\section{Child and Adolescent Paychiatry Section}

Chairman: Dr W. Lumsden Walker

Secretary: Dr H. C. Cameron

Representative Fellow on Council: Dr W. Lumsden Walker

Representative Member on Council: Dr H. C. Cameron

Executive Committee: Drs I. S. Berg, J. M. Black, J. Byng-

Hall, C. L. Casimir, J. Erulkar, E. A. Frommer, A. Gath,

M. J. Gay, Professors P. Graham, I. Kolvin, Drs B.

McCarthy, D. G. Melville Thomas, W. Parry-Jones, P.

Pinkerton, L. G. Scarth, C. Wardle, J. Wells

Co-opted: Drs A. D. Black, E. Kapp, A. R. Nicol, J. Powell, A. M. Smith

Observer: Dr L. Brierley

Collegiate Trainees Representative: Dr Oliver Shanks

Dependence/Addiction Group

Chairman: Dr Brian Hore

Secretary: Dr M. I. Akhter

Executive Committee: Drs J. Madden, J. Morgan, A.P. Thorley

\author{
Biological Paychiatry Group \\ Chairman: Dr D. Richter \\ Secretary: Dr T. Crow
}

\section{The Department of Mental Handicap at St George's}

A new department of Psychiatry of Mental Handicap has been established at St George's Hospital Medical School, Tooting, London. The Professor, Dr Joan Bicknell, has been appointed and will take up her new post on the 1 May, 1980. Initially there will be two Senior Lecturers in the Psychiatry of Mental Handicap in the department, one providing a clinical service for Kingston and Richmond Area Health Authority with beds at Normansfield, Teddington, and the second providing a clinical service for the Merton, Sutton and Wandsworth Area Health Authority (T), with beds at 
various mental handicap units within that Area. Within the medical school, close links will be established with the departments of Psychiatry, Child Health, Epidemiology and Community Medicine. Non-medical members of this department will be appointed, representing the various therapeutic professions making a contribution to mental handicap. Teaching commitments are expected to be extensive, involving medical students from St George's and postgraduate students in psychiatry and mental handicap throughout the Region. As the name of this new department implies, there will be an emphasis in the research projects undertaken to learn more of the psychiatric disorders that affect the mentally handicapped and their families. It is hoped that a special interest in communication disorders in mental handicap will evolve, and some of the beds will be available for the mentally handicapped with severe behavioural problems perhaps requiring security.

The aims, therefore, of this new department are threefold: firstly to develop an effective teaching programme for undergraduates, postgraduates and non-medical personnel, secondly to undertake research that will throw further light on the inter-relationship between psychiatry and mental handicap, and thirdly to develop a dynamic and progressive service for the care of the mentally handicapped. It will be the long-term aim of the work of this department to attract and train postgraduate students in psychiatry of the highest calibre to meet the service needs of this branch.

\section{Forthcoming Events}

The University of Mancheater Faculty of Medieine invite registered medical practitioners to apply for a course in preparation for the Degree of Master of Seience (Psychiatry) starting in October 1980. The course will consist of part-time instruction during nine university terms. Teaching will include courses in basic sciences, psychology, statistics, neurology, clinical psychiatry, psychotherapy and the specialties. Candidates will be examined at the end of the third year and if successful will be invited to present a dissertation. Candidates should normally hold training posts at one of the psychiatric units in the Manchester region. Information: Professor D. Goldberg, University Hospital of South Manchester, West Didsbury, Manchester M20 8LR.

Professor W. A. Lishman will deliver the sixth Shorvon Memorial Lecture on 15 May 1980 at $5.00 \mathrm{pm}$ in the Lecture Theatre at the National Hospital, Queen Square, London WC1. Information and seat reservations: Hospital Secretary, Maida Vale Hospital, London W9 1TL.

A Workehop in Research Methods for Paychiatry will be held from 8 to 12 September 1980 at the University of York under the auspices of the Research Committee of the Royal College of Psychiatrists. This intensive residential course is

\section{Teaching Psychiatry in Ethiopia}

Assistance is urgently needed in teaching psychiatry to students in the Medical Faculty of Addis Ababa University. There are $\mathbf{4 0}$ students this year to spend a month whole-time in the specialty. Seniority in psychiatry is not important. The teaching period is from 21 July to 21 December 1980, in four-week blocks with two weeks vacation, but any short or long-term help would be valuable. Teaching is in English and there is a possibility of some financial support from the Inter-University Council.

Anyone interested should write for more information to Dr John W. Landells, Addis Ababa University, PO Box 1176, Addis Ababa, Ethiopia.

\section{World Congress of Rehabititation International}

Would any British psychiatrist (UK or North America) who will be attending the 1980 World Congress of Rehabilitation International in Winnipeg and who would be willing to give a short paper or take part in any discussion on 'Psychiatric Rehabilitation' please contact Dr A.O.A. Wilson, International Committee Against Mental Illness, Bangour Village Hospital, Broxburn, West Lothian, as soon as possible. It is regretted that no expenses are available.

planned to deal with practical aspects of carrying out psychiatric research, and is especially suited for psychiatrists in training, though others will not be excluded. Places will be limited, closing date for application is $1 \mathrm{July}$. Course fee (residence and meals included) will be about $\mathbf{1 1 0 0}$. Information and application forms: Professor A.C.P. Sims, University Department of Psychiatry, St James's University Hospital, Leeds, LS9 7TS.

'What Direction for Paychiatric Day Services?' is the title of a two-day MIND conference to be held at Central Hall, Westminster, London on 21 and 22 May 1980. Details and forms: Conference Secretary, MIND, 22 Harley Street, London W1.

The Tavistock Clinic in conjunction with the Tavistock Institute of Human Relations and the School of Family Psychiatry and Community Mental Health are holding a five-day conference on "Conflieting Pressures in the Setting of Paychotherapy-The Interface of Treatment and Management' from 21 to 25 July 1980. Details and forms: Mrs Janet Clark, Executive Officer (Training), Tavistock Institute of Human Relations, 120 Belsize Lane, London NW3. 